\title{
THE IMPACT OF COPPER IONS ON OXIDATIVE STRESS IN GARDEN CRESS Lepidium sativum
}

\author{
WPEYW JONÓW MIEDZI NA STRES OKSYDACYJNY \\ U PIEPRZYCY SIEWNEJ Lepidium sativum
}

\begin{abstract}
Normal oxygen metabolism is an endogenous source of reactive oxygen species (ROS). The source of ROS are also many environmental factors including heavy metals. In certain concentration range, the presence of ROS is necessary to maintain proper cell function. Thus, cells have many mechanisms, which role is focused on maintaining a constant concentration of ROS. Imbalance between the formation of ROS and action of a protective antioxidant system leads to oxidative stress. This may results with a damage to the structure of proteins, lipids and nucleic acids, which in turn can lead to disturbances in the functioning of the cell and even to the death. The aim of the study was to evaluate the effect of copper ions on the metabolic activity of garden cress Lepidium sativum L. The action of copper ions with different concentrations was treated seeds. After four, six and eight days after planting in the leaves of garden cress were determined the specific activity of guaiacol peroxidase (GPOX), lipid peroxidation and protein content. Additionally intake of copper ions was determined using adsorption spectrometry technique. The results revealed that the applied doses of copper ions affected the activity of guaiacol peroxidase. The highest enzyme activity was found in plant material, which was treated with dose of copper ions $1000 \mathrm{mg} / \mathrm{dm}^{3}$ regardless of day. In the same samples the lowest level of lipid peroxidation was found. The highest concentrations of total proteins was found in samples treated with the highest dose of copper ions. The copper content in the tested plant material is correlated with the applied dose of copper ions. Our results indicate reliable correlations between copper content and values of oxidative stress biomarkers in plant tissues.
\end{abstract}

Keywords: Lepidium sativum, copper, oxidative stress

\section{Introduction}

Reactive oxygen species (ROS) have important roles in cell signaling and are a natural product of the normal oxygen metabolism in the cell. This is an endogenous source of ROS. The source of ROS are also many environmental factors, exogenous sources, which can be divided into two groups: abiotic and biotic. Abiotic sources of ROS are including UV radiation, high temperature, freezing, drought and xenobiotics such as drugs or heavy metals. Biotic sources are pathogens such as fungi or bacteria. In certain concentration range, the presence of ROS is necessary to maintain proper cell function such as regulation of gene expression governing such processes as cell cycle, growth and development.

\footnotetext{
${ }^{1}$ Independent Chair of Biotechnology and Molecular Biology, University of Opole, ul. kard. B. Kominka 6, 45-032 Opole, Poland, phone +48 774016050

*Corresponding author: agarombel@uni.opole.pl
} 
Furthermore, ROS is involved in plant signal systems. The production of reactive oxygen species is normally carefully controlled by the plant. Thus, cells have many mechanisms, enzymatic and non-enzymatic, which role is focused on maintaining a constant concentration of ROS. Plants possess specific antioxidant enzymes such as peroxidase, catalase and superoxide dismutase and low-molecular weight antioxidants like ascorbate, glutathione, tocopherols, flavonoids and carotenoids. Imbalance between the formation of ROS and action of a protective antioxidant system leads to oxidative stress, especially when plants are exposed to abiotic stress. This may results with a damage to the structure of proteins, lipids and nucleic acids, which in turn can lead to disturbances in the functioning of the cell and even to the death [1,2].

Copper is classified as heavy metal but, contrary to cadmium, lead or mercury, is an essential micronutrient for plant, playing an important role in maintaining plants natural metabolism and growth. Copper is a common cofactor for many enzymes including oxidases and certain proteases, is included in the composition of several proteins, which participate in numerous processes crucial for vital functions of the cell. It is known that $\mathrm{Cu}$ binds to chromosomes participating in the maintenance of their structure. On the other hand copper in excess is also an inhibitor of various physiological functions, for example root growth inhibition. Above an optimal level becomes toxic (above $30 \mathrm{ppm}$ ). Copper as a transition, very active metal has ability to produce reactive oxygen species and thus may be responsible for oxidative stress in plants [3,4]. Copper is widely distributed in nature, mainly because of human activities. Use of $\mathrm{Cu}$-bearing compounds in agriculture for combating soil pathogens results in its accumulation in the soil and plants. The effect of $\mathrm{Cu}$ excess is clearly manifested in suppression of plant growth and disturbance of photosynthesis. Furthermore, excess $\mathrm{Cu}$ in plants caused changes in activity and the content some components of antioxidant system, such as specific antioxidant enzymes, low-molecular nonprotein antioxidant and metal-binding SH proteins [2].

The aim of the study was to evaluate the effect of copper ions on the metabolic activity of garden cress Lepidium sativum.

\section{Materials and methods}

\section{Plant materials and treatments}

Lepidium sativum L. is commonly known as garden cress. Its a small, fast growing annual herbaceous plant, that is native to Egypt and west Asia, but now is cultivated in the entire World. The edible is the whole plant and seeds, which have health promoting properties, so is functional food ingredient. This plant is a rich source of vitamins, minerals, unsaturated fatty acid and phenolic compounds $[5,6]$.

Seeds of L. sativum ( $5 \mathrm{~g}$ ) were treatment with different concentrations of $\mathrm{Cu}^{2+}$ supplied in $\mathrm{CuSO}_{4}$ solution: 0 (control), 500 and $1000 \mathrm{mg} / \mathrm{dm}^{3}$. Each treatment was made in five replicates. After 12 hours of $\mathrm{Cu}^{2+}$ treatment the seeds were washed with sterile water and sowed on Petri dishes. The cultivation was carried out in growth chamber in a photoperiodic system day/night $14 / 10$ hours at temperature $20 / 16^{\circ} \mathrm{C}$ respectively and $70 \%$ relative humidity. Irrigation with Knap solution was provided in sufficient quantities for plant growth. After four, six and eight days after planting in the leaves of garden cress were determined protein content, the specific activity of guaiacol peroxidase (GPOX), lipids peroxidation and copper content. 


\section{Guaiacol peroxidase extraction and measuring of activity}

The specific activity of guaiacol peroxidase (GPOX) was determined spectrophotometrically using guaiacol as the substrate and $\mathrm{H}_{2} \mathrm{O}_{2}$ as the hydrogen donor. By the oxidation of guaiacol is formed coloured tetraguaiacol (extinction coefficient $\left.26.6 \mathrm{mM}^{-1} \mathrm{~cm}^{-1}\right)$.

For enzyme extraction $1 \mathrm{~g}$ of shoots was homogenized using a chilled mortar and pestle with $2 \mathrm{~cm}^{3}$ of $0.1 \mathrm{M}$ sodium phosphate buffer $(\mathrm{pH}=7.0)$. The extraction procedure was carried out on ice. The homogenate was centrifuged for $20 \mathrm{~min}$ at $10000 \mathrm{rpm}$ (revolutions per minute) at $4{ }^{\circ} \mathrm{C}$. The supernatant was used of protein and enzyme activity measurement. Guaiacol peroxidase activity GPOX was determined according to the modified method by Zaharieva et al. [7]. The reaction mixture $\left(5.0 \mathrm{~cm}^{3}\right)$ consist of $0.1 \mathrm{M}$ phosphate buffer $(\mathrm{pH}=7.0), 38 \mathrm{mM} \mathrm{H}_{2} \mathrm{O}_{2}$ and $4 \mathrm{mM}$ guaiacol. The reaction was started by the addition of $0.2 \mathrm{~cm}^{3}$ supernatant (enzyme extract). Absorption intensity of extractions was determined after 1 minute in wave length $470 \mathrm{~nm}$. The enzymatic activity of GPOX was calculated in terms of the protein content of the sample and was expressed in $\mu \mathrm{mol}$ per minute and milligram of protein.

\section{Determination of protein content}

The amount of total protein of shoots was measured by Lowry method using bovine serum albumin (BSA) as standard [8]. Absorption intensity of extractions was determined in wave length $750 \mathrm{~nm}$ and the results were reported according to $\mathrm{mg} / \mathrm{g} \mathrm{f.w}$. (fresh weight).

\section{Determination of lipid peroxidation}

Lipid peroxidation was measure as the amount of malondialdehyde (MDA) determined by thiobarbituric acid (TBA) reaction as described by Heath and Packer [9]. Briefly, $0.3 \mathrm{~g}$ of shoots were homogenized in $4 \mathrm{~cm}^{3}$ of $0.25 \%(\mathrm{w} / \mathrm{v})$ thiobarbituric acid (TBA) in $10 \%(\mathrm{w} / \mathrm{v})$ trichloroacetic acid (TCA) using mortar and pestle. The homogenate was heated at $95^{\circ} \mathrm{C}$ for $30 \mathrm{~min}$, quickly cooled in an ice bath and then centrifuged at $10000 \mathrm{rpm}$ for $10 \mathrm{~min}$. The absorbance of supernatant was recorded at 532 and $600 \mathrm{~nm}$. The blank was $0.25 \%$ TBA in $10 \%$ TCA. The MDA concentration was calculated by subtracting the absorbance at $600 \mathrm{~nm}$ (nonspecific turbidity) using the extinction coefficient of $155 \mathrm{mM}^{-1} \mathrm{~cm}^{-1}$ and expressed in terms of $\mu \mathrm{mol} / \mathrm{g}$ f.w. [10].

\section{Determination of copper content}

The $L$. sativum samples (dry mass each of them was $0.400 \pm 0.001 \mathrm{~g}$ ) were mineralized in the mixture of nitric (V) acid and hydrochloric acid $\left(\mathrm{HNO}_{3} 65 \%: \mathrm{HCl} 37 \%=1: 3\right)$ using a Speedwave Four made by Berghof, DE microwave oven. The mineralization process temperature was $180^{\circ} \mathrm{C}$. MERCK company reagents were used to prepare solutions [11]. Copper was determined with the atomic absorption spectrometer iCE 3000 made by Thermo Electron Corporation (USA). The Instrument Detection Limit $(I D L)$ and the Instrument Quantification Limit $(I Q L)$ for copper were 0.0045 and $0.033 \mathrm{mg} / \mathrm{dm}^{3}$, respectively. The highest concentration of the calibration standard available from ANALTYIKA Ltd., Czech Republic, namely $5 \mathrm{mg} / \mathrm{dm}^{3}$, was assumed the upper limit of the linear relation between the concentration of the analyte and the instrument signal [12]. 
The quality control of measurements was assured by test analyses of the BCR 414 plankton and BCR-482 lichen reference materials from the Institute for Reference Materials and Measurements in Belgium. The obtained results are summarized in Table 1.

Table 1

Measured and certified values of $\mathrm{Cu}$ concentration in the BCR 414 plankton and the BCR 482 lichen reference material

\begin{tabular}{|c|c|c|c|c|c|c|c|c|c|}
\hline \multicolumn{5}{|c|}{ BCR 414 plankton } & \multicolumn{5}{|c|}{ BCR 482 lichen } \\
\hline \multirow{2}{*}{$\begin{array}{c}\text { Certified } \\
\text { value }\end{array}$} & \multirow{2}{*}{ \pm Uncertainty } & \multicolumn{2}{|c|}{ AAS } & \multirow{2}{*}{$D^{*}$} & \multirow{2}{*}{$\begin{array}{l}\text { Certified } \\
\text { value }\end{array}$} & \multirow{2}{*}{ \pm Uncertainty } & \multicolumn{2}{|c|}{ AAS } & \multirow{2}{*}{$D^{*}$} \\
\hline & & Mean & $\pm S D$ & & & & Mean & $\pm S D$ & \\
\hline \multicolumn{4}{|c|}{ [mg/kg d.m.] } & [\%] & \multicolumn{4}{|c|}{ [mg/kg d.m.] } & [\%] \\
\hline 29.5 & 1.3 & 27.8 & 1.9 & -5.8 & 7.03 & 0.19 & 6.54 & 0.18 & -7.0 \\
\hline
\end{tabular}

* Deviation - a difference between a measured value and a certified value, divided by the certified value

\section{Statistical analysis}

All experiments were carried out in five replications and mean values \pm standard error were presented. One-way analysis of variances (ANOVA) and t-Student's test were used to determine statistical differences between treatment samples and control using Excel Data Analysis. Differences were considered significant at the level of $p<0.05$. In order to assess the interdependence of copper content in L. sativum shoots and the tested oxidative stress markers a correlation analysis was performed using Excel Data Analysis.

\section{Results}

\section{Protein content}

In the present study, the highest content of total proteins was found in samples treated with the highest dose of $\mathrm{Cu}^{2+}\left(1000 \mathrm{mg} / \mathrm{dm}^{3}\right)$. While the content of total proteins in samples treated with lower dose of $\mathrm{Cu}^{2+}\left(500 \mathrm{mg} / \mathrm{dm}^{3}\right)$ was similar to a protein content in control samples. It is notable that for samples treated with copper ions, the highest content protein statistically significant was found in samples tested the fourth day (with the exception of dose of copper $1000 \mathrm{mg} / \mathrm{dm}^{3}$ ). The protein content in the subsequent days decreased (Fig. 1).

\section{Guaiacol peroxidase activity}

The highest specific activity of guaiacol peroxidase was found in plant material, which was treated with the highest dose of $\mathrm{Cu}^{2+}\left(1000 \mathrm{mg} / \mathrm{dm}^{3}\right)$, about 7 times more compared with the control sample. In the case of lower doses of $\mathrm{Cu}^{2+}\left(500 \mathrm{mg} / \mathrm{dm}^{3}\right)$ also increased significantly activity of enzyme compared to the control samples. The highest activity of GPOX was found in samples tested the fourth day, and then in the subsequent days statistically significant decreased (ANOVA, $p=0.002$ ). In the case of the highest dose of $\mathrm{Cu}^{2+}\left(1000 \mathrm{mg} / \mathrm{dm}^{3}\right)$, enzyme activity was similar regardless of the date of tests (Fig. 2). 


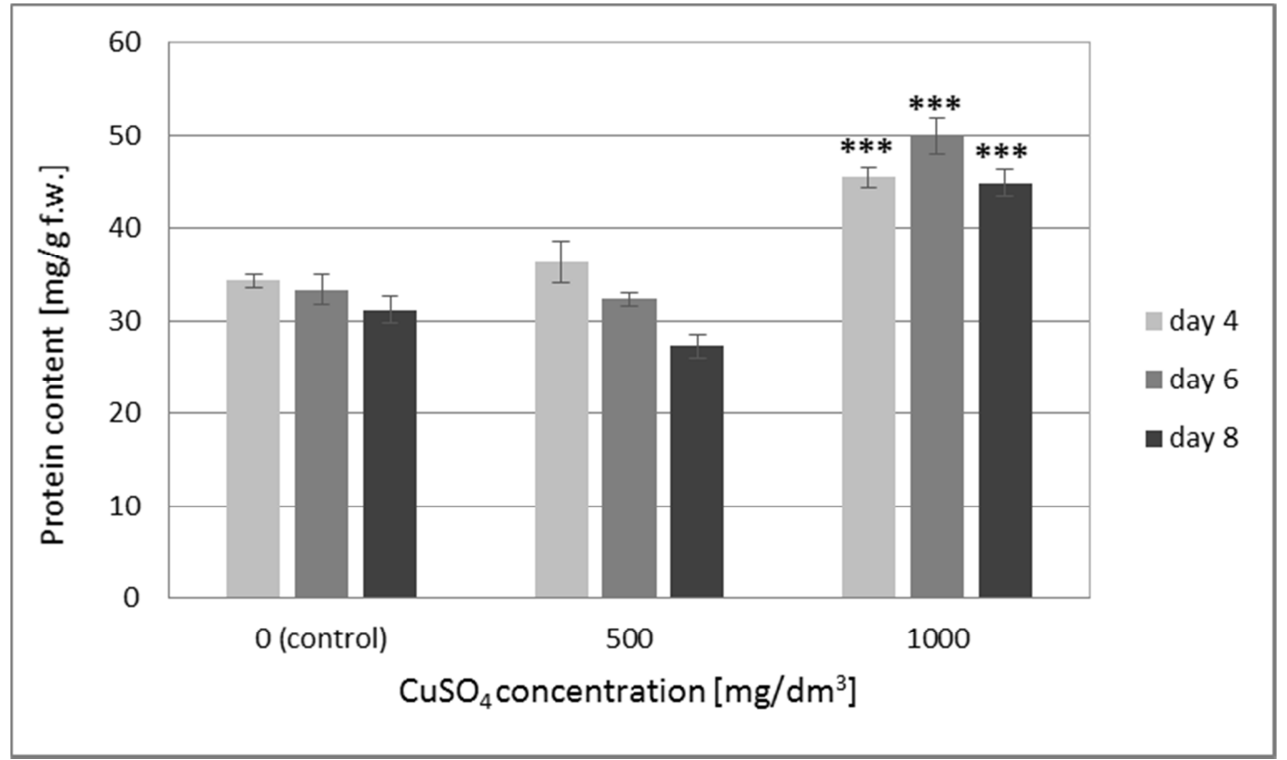

Fig. 1. Effects of different copper concentration on protein content in Lepidium sativum shoots (bars represent standard errors of the means, $n=5$ ). *** - significance level $p<0.001$ (Student's test) in relation to the control

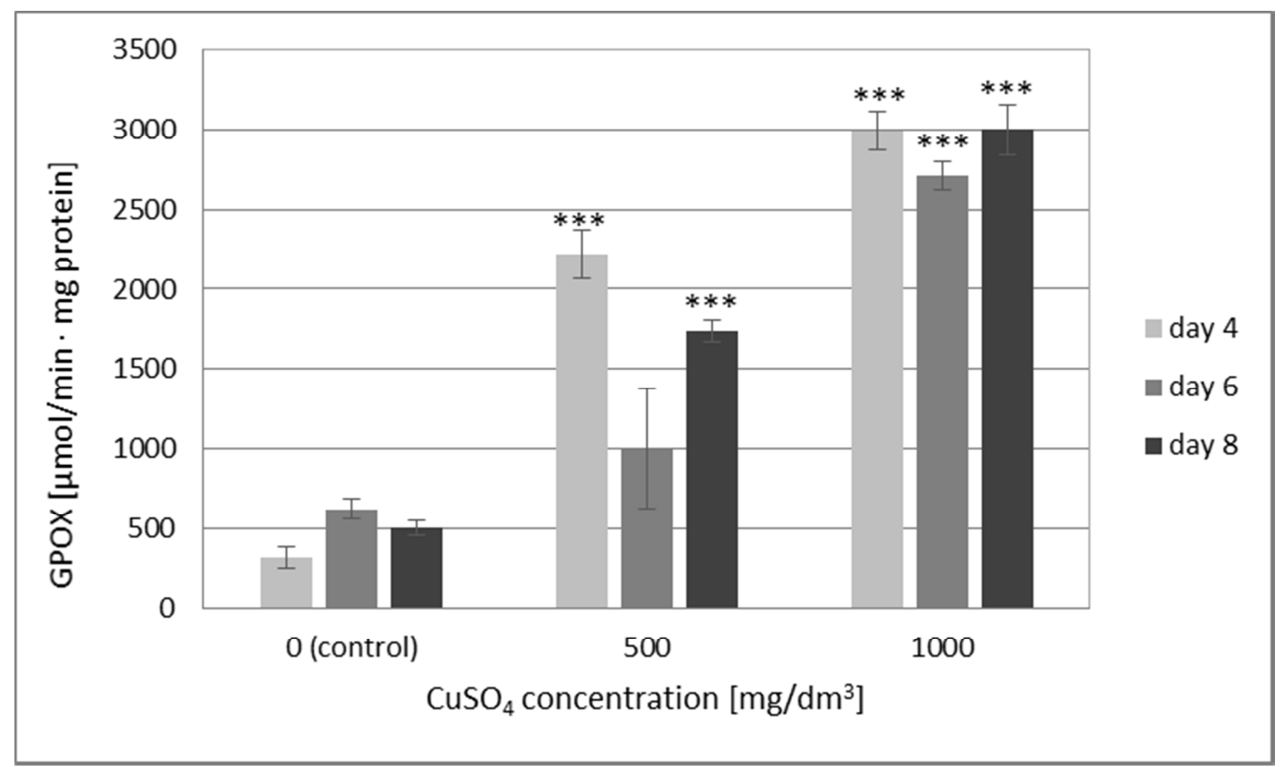

Fig. 2. Effects of different copper concentration on the specific activity of guaiacol peroxidase (GPOX) in Lepidium sativum shoots (bars represent standard errors of the means, $n=5$ ). *** - significance level $p<0.001$ (Student's test) in relation to the control 


\section{Lipid peroxidation}

Lipid peroxidation was measured as the amount of MDA determined by thiobarbituric acid reaction, which products are coloured. The results revealed that MDA concentrations in control samples and samples treated with lower dose of $\mathrm{Cu}^{2+}\left(500 \mathrm{mg} / \mathrm{dm}^{3}\right)$ were similar, without statistically significant differences. But very interesting is that the lowest level of lipid peroxidation was found in plants treated with dose of $\mathrm{Cu}^{2+} 1000 \mathrm{mg} / \mathrm{dm}^{3}$. This indicates that in plants treated with dose of $\mathrm{Cu}^{2+} 1000 \mathrm{mg} / \mathrm{dm}^{3}$ the very high peroxidase activity reduced lipid peroxidation (Fig. 3).

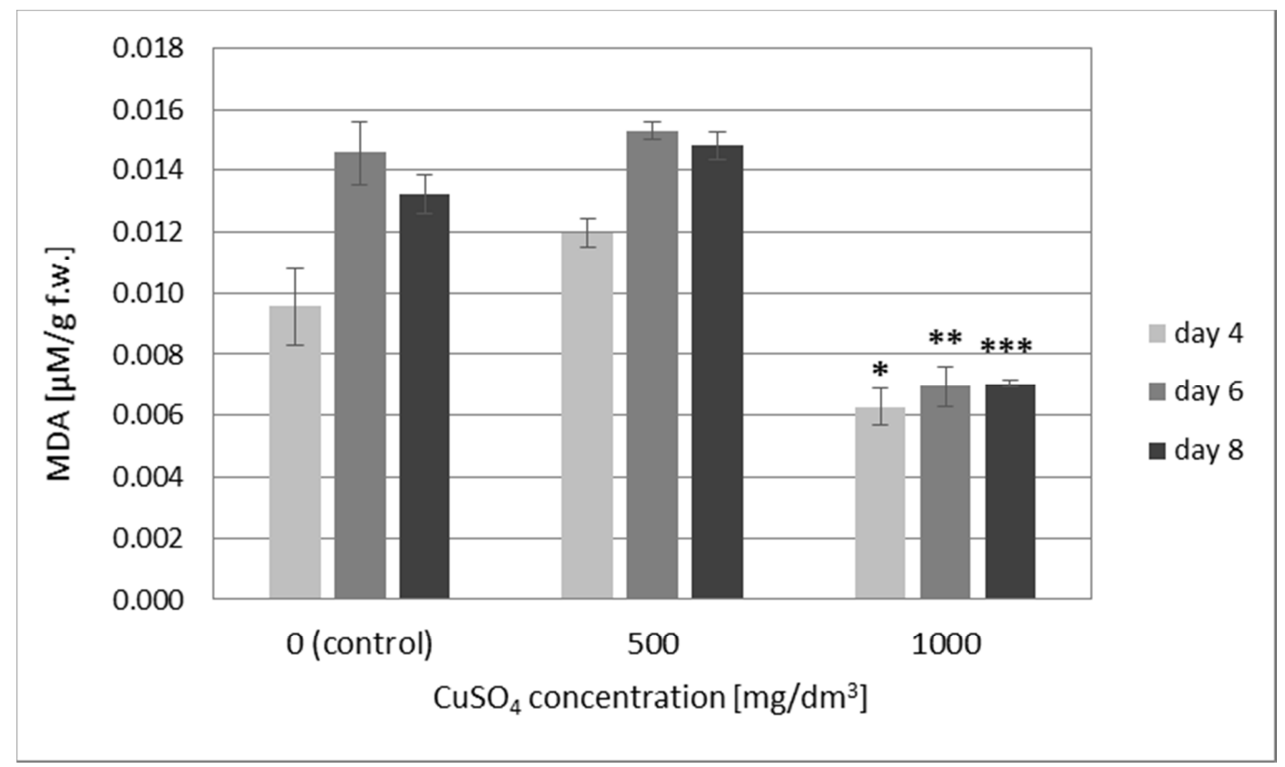

Fig. 3. Effects of different copper concentration on malondialdehyde (MDA) content in Lepidium sativum shoots (bars represent standard errors of the means, $n=5$ ). * - significance level of $p<0.05$ (Student's test) in relation to the control, $* *$ - significance level $p<0.01$ (Student's test) in relation to the control, $* * *$ - significance level $p<0.001$ (Student's test) in relation to the control

\section{Copper content}

The highest copper content was found in plants, which were treated with dose of copper ions $1000 \mathrm{mg} / \mathrm{dm}^{3}$ (even 200-fold higher than in control plants). Relatively lower copper content was in the shoot treated with dose of copper ions $500 \mathrm{mg} / \mathrm{dm}^{3}$ (Fig. 4).

Furthermore, the copper content in plants treated with lower dose of $\mathrm{Cu}^{2+}$ $\left(500 \mathrm{mg} / \mathrm{dm}^{3}\right)$ were significantly reduced in the subsequent days $(p<0.01$, ANOVA). In contrast, the copper content in plants treated with $1000 \mathrm{mg} / \mathrm{dm}^{3}$ were increased in the subsequent days $(p<0.01$, ANOVA). In the control sample, the copper content did not change.

It may be assumed, that in plant treated with dose of copper ions $1000 \mathrm{mg} / \mathrm{dm}^{3}$ was abnormal (disturbed) transport processes and elimination of copper ions. In plant samples treated with lower dose of copper ions, copper was involved in metabolic processes and its excess was effectively eliminated from the cell. 


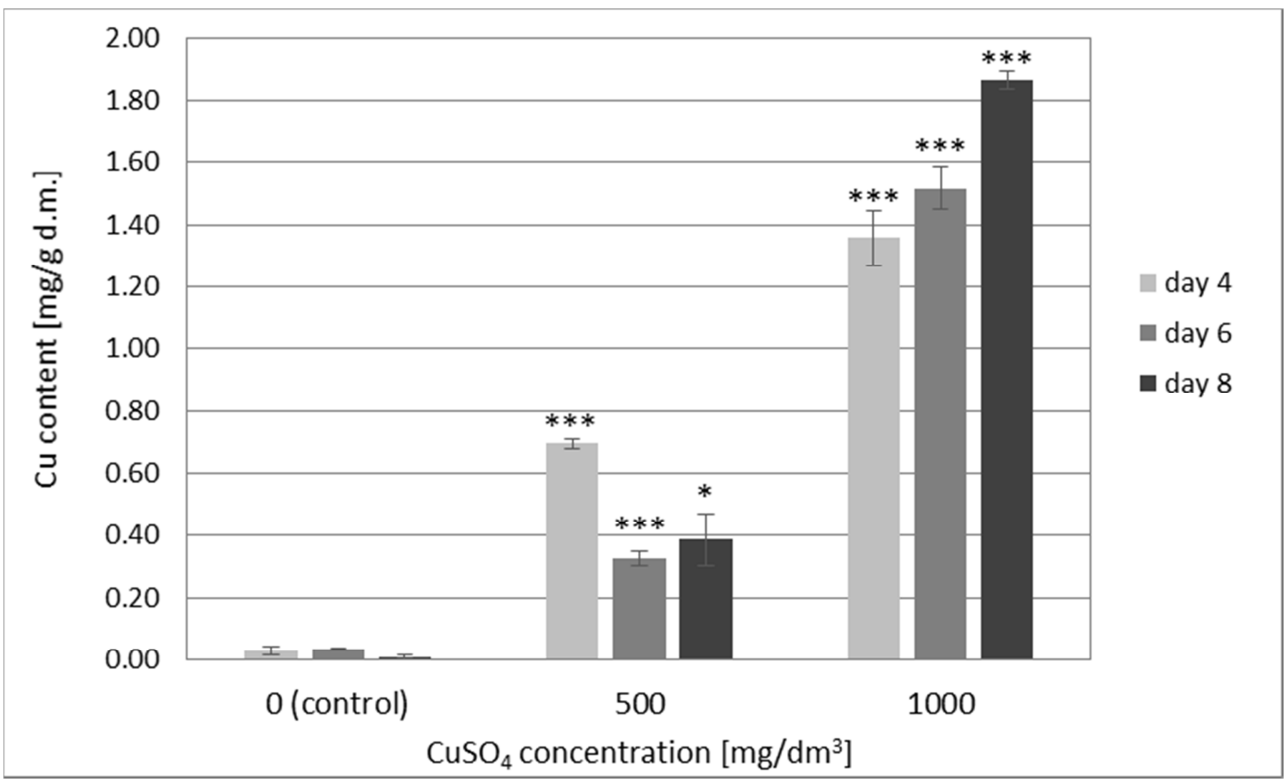

Fig. 4. Copper content in Lepidium sativum shoots under $\mathrm{Cu}^{2+}$ stresss (bars represent standard errors of the means, $n=5$ ). * - significance level of $p<0.05$ (Student's test) in relation to the control, $* *$ - significance level $p<0.01$ (Student's test) in relation to the control, $* * *$ - significance level $p<0.001$ (Student's test) in relation to the control

The correlation between copper content in shoots of $L$. sativum and the concentration of oxidative stress markers: MDA, protein and guaiacol peroxidase activity was investigated (Table 2). The analysis revealed a negative correlation between copper content and MDA concentration in shoots, particularly evident on day 6 and 8 of the study. In addition, a strong positive correlation between copper content in plant and GPOX activity and protein content were found.

Table 2

Correlation between copper content in shoots of Lepidium sativum and MDA concentration, GPOX activity and protein content

\begin{tabular}{|c|c|c|c|}
\hline \multirow{2}{*}{ Day } & \multicolumn{3}{|c|}{ Correlation coefficient $\boldsymbol{R}$} \\
\cline { 2 - 4 } & Cu content/MDA & Cu content/GPOX activity & Cu content/Protein content \\
\hline 4 & -0.47 & 0.98 & 0.97 \\
\hline 6 & -0.94 & 0.99 & 0.97 \\
\hline 8 & -0.93 & 0.94 & 0.91 \\
\hline
\end{tabular}

\section{Discussion}

Effects of metals have been studied intensively at the level of biochemical-physiological and metal accumulation in plant tissue [13, 14].

One of the effects of heavy metal-induced oxidative stress is alteration in protein metabolism. Therefore, protein content is used as an important indicator of the physiological status of plants [4]. Metal stress in plants usually leads to reduction of protein content [13-16]. However, in few cases, increase protein content was noted [4, 13, 17, 18]. 
The significance of this phenomenon is unknown [13]. The increased protein content may be due to the synthesis of stress related protein such as phytochelatins and antioxidative enzymes [18-20].

Enzyme activities might play a central role in cellular protection against the heavy metal induces oxidative stress [13]. One of them are peroxidases, located in almost all compartment of the plant cell. The main function of peroxidases is $\mathrm{H}_{2} \mathrm{O}_{2}$ degradation. Guaiacol peroxidase (GPOX, EC 1.11.17) decomposed $\mathrm{H}_{2} \mathrm{O}_{2}$ by oxidation of co-substrates such phenolic compounds and/or antioxidants [13,21].

Peroxidases are involved in many different plant processes, from germination to senescence, auxin metabolism, cell wall elongation, and protection against pathogens. Changes in the activity of peroxidases, especially GPOX, are used as sensitive markers of abiotic and biotic stresses in plants [22]. The activity of this enzyme generally increases under heavy metal stress [4], but in susceptible plants or from conditionally pure habitats, this enzyme are inhibited [2].

Similar to this study, stimulated GPOX was reported in $\mathrm{Cu}$-exposed Lemna gibba and Lemna minor [4], Brassica juncea [23], Lupinus luteus [24], Phaseolus vulgaris [25], Astragalus neo-mobayenii [26] and Allium sativum [27]. In addition, it was observed, that induction of GPOX activity in copper-treated plants of Beta vulgaris L. was higher in young leaves than in old leaves [28]. The high activity of guaiacol peroxidase in Lepidium sativum shoots treated by the highest dose of $\mathrm{Cu}^{2+}$ suggest resistance of this plants to copper stress.

One of the most oxidative damaging effects is the peroxidation of membrane lipids. Malondialdehyde (MDA) is one of the final products of plant cell membrane lipid peroxidation and is an important sign of membrane system injury, widely used as an indicator of oxidative stress in plants cells and tissues [13].

MDA content usually increases in plants with heavy metals including copper. Increases in the level of MDA have been found in plants treated with copper such as Eichornia crassipes [29], Potamogeton pusillus [30], Hydrilla verticillata [17], Spirodela polyrhiza [4], Brassica juncea [23], Astragalus neo-mobayenii [26], Beta vulgaris [28], Allium sativum [27] and Solanum nigrum [31].

However, similar to results of this study, reduced MDA contents were observed in $\mathrm{Cu}$-exposed Lemna gibba, Lemna minor [4] and Rosmarinus officinalis [32]. Decreased MDA content could be attributed to a higher activity of antioxidant enzymes, which can protect biomembranes from oxidative damage by lipid peroxidation [4, 32, 33].

The our results confirm that copper accumulation in plants depends on the concentration of metal ions in the growing medium [14, 34].

\section{Conclusion}

The highest content of total proteins and the highest specific activity of GPOX were found in plants of L. sativum treated with the highest dose of copper ions $\left(1000 \mathrm{mg} / \mathrm{dm}^{3}\right)$. In the same plants the decrease MDA concentration was found. This indicates that the increased peroxidase activity reduced lipid peroxidation in plants of L. sativum. Such a protective effect was not observed with dose of copper ions $500 \mathrm{mg} / \mathrm{dm}^{3}$.

Copper content in studied plants depends on the concentration of $\mathrm{CuSO}_{4}$ solution applied to soaking L. sativum seeds. In addition, the copper content in plants treated with dose of $\mathrm{Cu}^{2+} 500 \mathrm{mg} / \mathrm{dm}^{3}$ were significantly reduced in the subsequent days. In contrast, the 
copper content in plants treated with $1000 \mathrm{mg} / \mathrm{dm}^{3}$ were increased. It may be assumed that in plant treated with the highest dose of copper ions transport processes and elimination of copper ions was disturbed.

Our results indicate reliable correlations between copper content and values of oxidative stress biomarkers in plant tissues. Estimated correlation coefficients confirmed, that studied parameters strictly depends on copper ions concentration $(R=0.91-0.97)$. At the concentration of MDA negative correlation was found, unlike other indicators in which a clear positive correlation was showed.

\section{References}

[1] Pasternak T, Potters G, Caubergs R, Jansen MAK, Complementary interactions between oxidative stress and auxins control plant growth responses at plant, organ and cellular level. J Exp Bot. 2005;56:1991-2001. DOI: $10.1093 / \mathrm{j} x \mathrm{~b} / \mathrm{eri} 196$.

[2] Raldugina GN, Krasavina MS, Lunkova NF, Burmistrova NA. Resistance of plants to Cu stress: transgenesis. In: Ahmad P, editor. Plant Metal Interaction. Emerging Remediation Techniques. Elsevier. 2016:69-114. DOI: 10.1016/B978-0-12-803158-2.00004-7.

[3] Stohs SJ, Bagchi D. Oxidative mechanisms in the toxicity of metal ions. Free Radic Biol Med. 1995;18:321-336. DOI: 10.1016/0891-5849(94)00159-H.

[4] Doğanlar ZB, Metal accumulation and physiological responses induced by copper and cadmium in Lemna gibba, L. minor and Spirodela polyrhiza. Chem Speciat Bioavialabil. 2013;15:79-88. DOI: 10.3184/095422913X13706128469701.

[5] Indumathy R, Aruna A. Free radical scavenging activities, total phenolic and flavonoid content of Lepidium sativum (Linn.). Int J Pharm Pharm Sci. 2013;5:634-637. https://www.researchgate.net/publication/ 288293438_Free_radical_scavenging_activities_total_phenolic_and_flavonoid_content_of_Lepidium_sativu m_Linn.

[6] Zia-Ul-Haq M, Ahmad S, Calani L, Mazzeo T, Del Rio D, Pellegrini N, et al. Compositional study and antioxidant potential of Ipomoea hederacea Jacq. and Lepidium sativum L. seeds. Molecules. 2012;17:10306-10321. DOI: 10.3390/molecules170910306.

[7] Zaharieva T, Yamashita K, Matsumoto H. Iron deficiency induced changes in ascorbate contetnt and enzyme activities related to ascorbate metabolism in cucumber roots. Plant Cell Physiol. 1999;40:273-280.

[8] Lowry OH, Rosenbrough NJ, Farr AL, Randall RJ. Protein measurement with the Folin phenol reagent. J Biol Chem. 1951;193:265-275. http://www.jbc.org/content/193/1/265.long.

[9] Heath RL, Packer L. Photoperoxidation in isolated chloroplast. I. Kinetics and stoichiometry of fatty acid peroxidation. Arch Biochem Biophys. 1968;125:189-198. DOI: 10.1016/0003-9861(68)90654-1.

[10] Ibrahim MM, Bafeel SO. Alteration of gene expression, superoxide anion radical and lipid peroxidation induces by lead toxicity in leaves of Lepidium sativum. J Anim Plant Sci. 2009;4:281-288. http://www.m.elewa.org/JAPS/2009/4.1/6.pdf.

[11] Rajfur M, Krems P, Kłos A, Kozłowski R, Jóźwiak MA, Kř́̌ž J, et al. Application of algae in active biomonitoring of the selected holding reservoirs in Swietokrzyskie Province. Ecol Chem Eng S. 2016;23(2):237-247. DOI: 10.1515/eces-2016-0016.

[12] iCE 3000 Series AA Spectrometers Operators Manuals. Cambridge: Thermo Fisher Scientific; 2011. http://photos.labwrench.com/equipmentManuals/9291-6306.pdf.

[13] Lu Y, Li XR, He MZ, Wang ZN, Tan HJ. Nickel effects on growth and antioxidative enzymes activities in desert plant Zygophyllum xanthoxylon (Bunge) Maxim. Sci Cold Arid Regions. 2010;2:436-444. DOI: 10.3724/SP.J.1226.2010.00436.

[14] Keser G. Effects of irrigation with wastewater on the physiological properties and heavy metal content in Lepidium sativum L. and Eruca sativa (Mill.). Environ Monit Assess. 2013;185:6209-6217. DOI: 10.1007/s10661-012-3018-x.

[15] Upadhyay RK, Panda SK. Copper-induced growth inhibition, oxidative stress and ultrastructural alterations in freshly grown warer lettuce (Pistia stratiotes L.). Comptes Rendus Biol. 2009;332:623-632. DOI: 10.1016/j.crvi.2009.03.001.

[16] Kanoun-Boulé M, Vicente JAF, Nabais C, Prasad MNV, Freitas H. Ecophysiological tolerance of duckweeds exposed to copper. Aquat Toxicol. 2009;91:1-9. DOI: 10.1016/j.aquatox.2008.09.009. 
[17] Srivastava S, Mishra S, Tripathi RD, Dwivedi S, Gupta DK. Copper-induced oxidative stress and responses of antioxidants and phytochelatins in Hydrilla verticillata (L.f) Royale. Aquatic Toxicol. 2006:80:405-415. DOI: 10.1016/j.aquatox.2006.10.006.

[18] Rolli NM, Suvarnaknandi SS, Mulgund GS, Ratageri RH, Taranath TC. Biochemical responses and accumulation of cadmium in Spirodela polyrhiza. $J$ Environ Biol. 2010;31:529-532. http://www.jeb.co.in/journal_issues/201007_jul10/paper_23.pdf.

[19] Cuypers A, Koistnen KM, Kokko H, Kärenlampi S, Auriola S, Vangronsveld J. Analysis of bean (Phaseolus vulgaris L.) proteins affected by copper stress. J Plant Physiol. 2005:162:383-392. DOI: 10.1016/j.jplph.2004.07.018.

[20] Mishra S, Srivastava S, Tripathi RD, Kumar R, Seth CS, Gupta DK. Lead detoxification by Coontail (Ceratophyllum dermersum L.) involves induction of phytochelatins and antioxidant system in response to its accumulation. Chemosphere. 2006:65:1027-1039. DOI: 10.1016/j.chemosphere.2006.03.033.

[21] Blokhina O, Virolainen E, Fagerstedt KV, Antioxidants, oxidative damage and oxygen deprivation stress: a review. Annal Botany. 2003;91:179-194. DOI: 10.1093/aob/mcf118.

[22] Passardi F, Longet D, Penel C, Dunand C. The class III peroxidase multigenic family in rice and its evolution in land plants. Phytochemistry. 2004;65(13):1879-1893. DOI: 10.1016/j.phytochem.2004.06.023.

[23] Singh S, Singh S, Ramachandran V, Eapen S. Copper tolerance and response of antioxidative enzymes in axenically grown Brassica juncea (L.) plants. Ecotoxicol Environ Safety. 2010;73:1975-1981. DOI: 10.1016/j.ecoenv.2010.08.020.

[24] Mourato MP, Martins LL, Camposa-Andrada MP. Physiological responses of Lupinus luteus to different copper concentrations. Biol Plantarium. 2009;53:105-111. https://link.springer.com/content/pdf/ 10.1007\%2Fs10535-009-0014-2.pdf.

[25] Cuypers A, Vangronsveld J, Clijsters H. Peroxidases in roots and primary leaves of Phaseolus vulgaris copper and zinc phytotoxicity: a comparison. J Plant Physiol. 2002;159:869-876. DOI: 10.1078/0176-1617-00676.

[26] Karimi P, Khavari-Nejad RA, Niknam V, Ghahremaninejad F, Najafi F. The effects of excess copper on antioxidative enzymes, lipid peroxidation, proline, chlorophyll, and concentration of $\mathrm{Mn}, \mathrm{Fe}$, and $\mathrm{Cu}$ in Astragalus neo-mobayenii. Sci World J. 2012;2012:1-6. DOI: 10.1100/2012/615670.

[27] Meng Q, Zou J, Zou J, Jiang W, Liu D. Effect of $\mathrm{Cu}^{2+}$ concentration on growth, antioxidant enzyme activity and malondialdehide content in garlic (Allium sativum L.). Acta Biol Cracoviensia Series Botan. 2007;49(1):95-101. http://www2.ib.uj.edu.pl/abc/pdf/49_1/12meng.pdf.

[28] Morales JML, Rodriguez-Monroy M, Sepúlveda-Jiménez G. Betacyanin accumulation and guaiacol peroxidase activity in Beta vulgaris L. leaves following copper stress. Acta Soc Bot Pol. 2012;81:193-201. DOI: $10.5586 /$ asbp.2012.019.

[29] Hu C, Zhang L, Hamilton D, Zhou W, Yang T, Zhu D. Physiological responses induced by copper bioaccumulation in Eichhornia crassipes (Mart.). Hydrobiologia. 2007;579:211-218. DOI: 10.1007/s10750-006-0404-9.

[30] Monferrán MV, Sánchez Agudo JA, Pignata ML, Wunderlin DA. Copper-induced response of physiological parameters and antioxidant enzymes in the aquatic macrophyte Potamogeton pusillus. Environ Pollut. 2009; 157:2550-2576. DOI: 10.1016/j.envpol.2009.02.034.

[31] Fidalgo R, Azenha M, Silve AF, de Sousan A, Santiago A, Ferraz P, et al. Copper-induced in Solanum nigrum L. and antioxidant defense system responses. Food Energy Security. 2013;2:70-80. DOI: 10.1002/fes3.20.

[32] Hejazi-Mehrizi M, Shariatmadari H, Khoshgoftarmanesh AH, Dehghani F. Copper effects on growth, lipid peroxidation, and total phenolic content of rosemary leaves under salinity stress. J Agr Sci Technol. 2012;14(1):205-212. https://www.researchgate.net/publication/260423986_Copper_Effects_on_Growth_Lipid_Peroxidation_and _Total_Phenolic_Content_of_Rosemary_Leaves_under_Salinity_Stress.

[33] Seliga H. Antioxidative activity of copper in root nodules of yellow lupin plants. Acta Physiol Plant. 1999;21:427-431.

[34] Szczodrowska A, Kulbat K, Smolińska B, Leszczyńska J. Accumulation of metal ions in selected plants from Brassicaceae and Lamiaceae families. Biotechnol Food Sci. 2016;80:29-42. http://www.bfs.p.lodz.pl. 